Hydrology and Earth System Sciences, 6(3), 339-350 (2002) C $\quad$ EGS

\title{
Hydrological application of the INCA model with varying spatial resolution and nitrogen dynamics in a northern river basin
}

\author{
K. Rankinen, A. Lepistö and K. Granlund \\ Finnish Environment Institute, P.O.Box 140, FIN-00251 Helsinki, Finland
}

Email for corresponding author: katri.rankinen@ymparisto.fi

\begin{abstract}
As a first step in applying the Integrated Nitrogen model for CAtchments (INCA) to the Simojoki river basin $\left(3160 \mathrm{~km}^{2}\right)$, this paper focuses on calibration of the hydrological part of the model and nitrogen $(\mathrm{N})$ dynamics in the river during the 1980s and 1990s. The model application utilised the GIS land-use and forest classification of Finland together with a recent forest inventory based on remote sensing. In the INCA model, the Hydrologically Effective Rainfall (HER) is used to drive the water flow and N fluxes through the catchment system. HER was derived from the Watershed Simulation and Forecast System (WSFS). The basic component of the WSFS is a conceptual hydrological model which simulates runoff using precipitation, potential evapotranspiration and temperature data as inputs. Spatially uniform, lumped input data were calculated for the whole river basin and spatially semi-distributed input data were calculated for each of the nine sub-basins. When comparing discharges simulated by the INCA model with observed values, a better fit was obtained with the semi-distributed data than with the spatially uniform data $\left(\mathrm{R}^{2} 0.78 v .0 .70\right.$ at Hosionkoski and $0.88 v .0 .78$ at the river outlet). The timing of flow peaks was simulated rather well with both approaches, although the semi-distributed input data gave a more realistic simulation of low flow periods and the magnitude of spring flow peaks. The river basin has a relatively closed N cycle with low input and output fluxes of inorganic N. During 1982-2000, the average total $\mathrm{N}$ flux to the sea was 715 tonnes $\mathrm{yr}^{-1}$, of which $6 \%$ was $\mathrm{NH}_{4}-\mathrm{N}, 14 \% \mathrm{NO}_{3}-\mathrm{N}$, and $80 \%$ organic $\mathrm{N}$. Annual variation in river flow and the concentrations of major $\mathrm{N}$ fractions in river water, and factors affecting this variation are discussed.
\end{abstract}

Keywords: northern river basin, nitrogen, forest management, hydrology, dynamic modelling, semi-distributed modelling

\section{Introduction}

Nitrogen concentrations and fluxes in rivers reflect the integration of catchment $\mathrm{N}$ sources (non-point sources, atmospheric $\mathrm{N}$ deposition, direct effluent discharges, mineralisation) and sinks (plant uptake, immobilisation, denitrification). Furthermore, the multiple $\mathrm{N}$ sources in a catchment influence the options for water utilisation downstream and influence the water quality of estuarine and marine areas. The eutrophication of estuaries and marine areas is one of the best-documented and best-understood consequences of human-altered $\mathrm{N}$ cycling. In the Baltic Sea, the concentrations of $\mathrm{NO}_{3}-\mathrm{N}$ have increased notably during recent decades (e.g. Wulff and Rahm, 1988; Kuparinen and Tuominen, 2001), contributing to increased algal blooms and other harmful eutrophication effects, but the causal factors are still not clear (e.g. Kahru et al., 1994).
Typical hydrological features in the boreal zone in northern Finland are long (5-7 months) winters with continuous snow cover, deep soil frost and ice cover over rivers and lakes. The annual hydrological pattern is dominated by a snowmelt-induced spring flood in late AprilMay. Smaller flow peaks occur in autumn due to rainfall. Most nutrient leaching occurs during these high flow periods. It is of key importance to know how accurate the spatial resolution of hydrological input should be when modelling nutrient fluxes in large river basins of the boreal zone.

According to spatial distribution, hydrological models can be classified as lumped $v$. distributed models. In lumped models, e.g. the EPIC model (Williams et al., 1984), all parameters and variables represent an average value covering the entire area. In distributed models, e.g. the SHE 
model (Abbott et al., 1986), spatial variation of input parameters and variables is accounted for in such a way that they reflect physical properties in different parts of the modelled area. Between these two degrees of complexity in hydrological models are intermediate, semi-distributed models. Among these, the HBV-96 model (Lindström et al., 1997) allows division of a catchment into sub-basins and elevation/vegetation zones, and the SWAT model (Arnold et al., 1998) permits division into sub-basins and hydrologically representative units on the basis of different land use/soil combinations within the sub-basins. The Watershed Forecast System (WSFS) of the Finnish Environment Institute (SYKE) (Vehviläinen, 1994) utilizes a semi-distributed, conceptual approach when calculating runoff from observations of precipitation, temperature and potential evapotranspiration. The INCA model used here (version 1.6) allows two kinds of hydrological input data. Either lumped input data can be given for the whole river basin, or separate input data can be given for individual sub-basins.

Forest management can affect many aspects of basin streamflow. Total runoff generally increases with forest disturbance as a result of reduced interception and transpiration. However, most studies of the hydrological impacts of forest disturbance have been conducted in small scales $\left(<1\right.$ to $\left.10 \mathrm{~km}^{2}\right)$ (e.g. Bosch and Hewlett, 1982; Seuna, 1988; Sachs et al., 1998), and the cumulative impacts on streamflow in medium- or large-basin $\left(\sim 1000 \mathrm{~km}^{2}\right)$ scales remain unclear (e.g. Cheng 1989). Buttle and Metcalfe (2000) found very limited streamflow responses to harvesting in large-scale basins in Ontario, Canada, with no definitive changes in annual runoff or peak flow magnitude and timing. This suggests that changes in $\mathrm{N}$ cycling due to forest management are related more to soilvegetation processes than to hydrological changes. Forestry practices such as clear-cutting and drainage may upset the nitrogen cycle by decreasing plant uptake, enhancing mineralization, altering the accumulation rate of inorganic nitrogen in the soil, and increasing nitrate leaching and denitrification (Wiklander et al., 1991; Gundersen, 1992).

The main emphasis of this study was to test the behaviour of the INCA model (Wade et al., 2002) in northern boreal conditions. The model was applied to the Simojoki river basin, where the major human influences on $\mathrm{N}$ fluxes are forest management and atmospheric $\mathrm{N}$ deposition. Firstly, hydrological calibration of the INCA model is discussed. Secondly, the differences in model response caused by semidistributed and lumped hydrological input are compared and thirdly, annual variation in river flow and $\mathrm{N}$ concentration in river water during 1982-2000, and factors affecting this variation are discussed in order to develop a conceptual understanding for the next phase of the modelling process.

\section{Material and methods}

\section{SITE DESCRIPTION, HYDROLOGICAL MONITORING AND WATER SAMPLING}

The River Simojoki discharges to the Gulf of Bothnia in the Baltic Sea. The river basin $\left(3160 \mathrm{~km}^{2}\right)$ is composed of nine sub-basins (Fig. 1) (Ekholm, 1993). Over the period 1961-1975, mean annual precipitation was $650-750 \mathrm{~mm}$, mean annual evapotranspiration about $330 \mathrm{~mm}$ and mean annual runoff $350-450 \mathrm{~mm}$. There are about $170-180$ winter

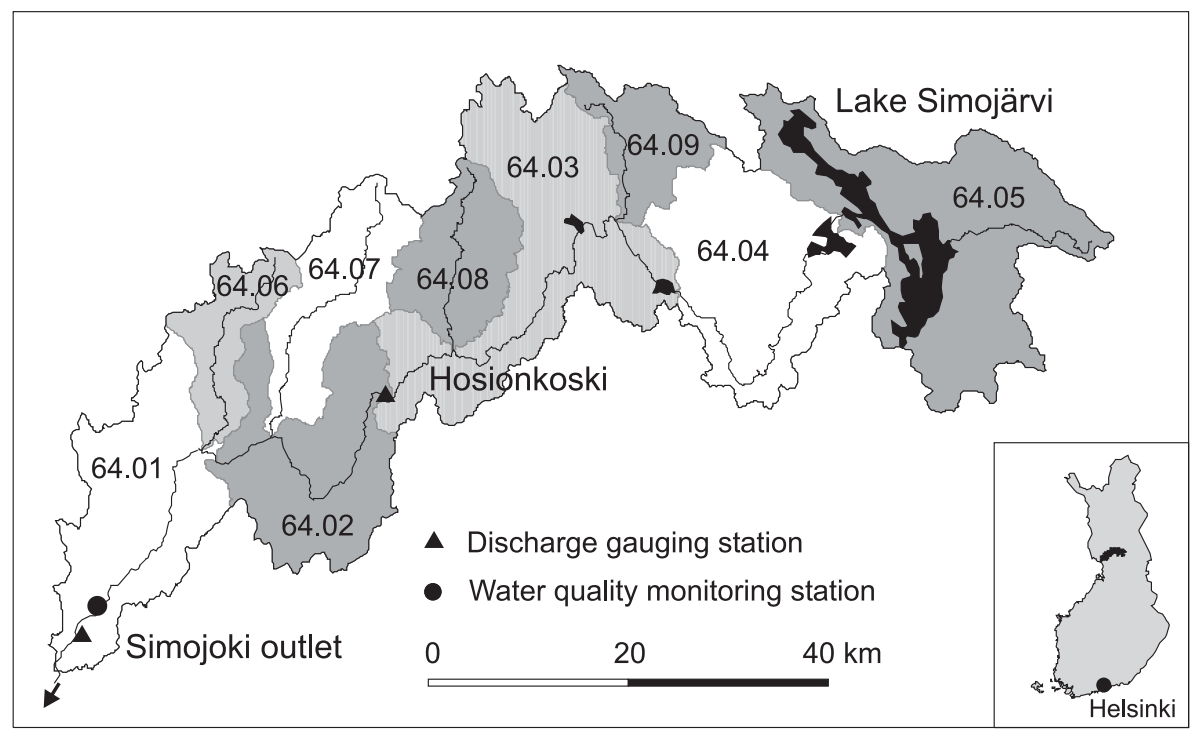

Fig. 1. Location of the river Simojoki basin (sub-basins 64.01-64.09) in northern Finland 
days and the mean annual temperature is $+0.5-+1.5^{\circ} \mathrm{C}$. The duration of the snow cover is from the middle of November to May. The River Simojoki freezes up at the end of October or the beginning of November and the ice cover usually breaks up in the middle of May.

The River Simojoki is a salmon river in near-natural state, and the dominant human impact is forestry, mainly forest drainage and cutting. The Simojoki river basin is located in the Fenno-Scandian Shield with bedrock consisting of granites and gneisses. It is located in the northern boreal zone where forests in mineral soil, and in organic soil, with varying types of peat-land, dominate. The major tree species are Norway spruce (Picea abies), Scots pine (Pinus sylvestris) and birch (Betula spp.).An average of $0.5 \%$ of the total catchment area is felled annually. Forestry drainage was most intensive during the 1960s and 1970s, and by 1991 over $30 \%$ i.e. $1000 \mathrm{~km}^{2}$ of the total catchment area had been drained (Perkkiö et al., 1995). Currently, supplementary drainage works are being carried out in those old drainage areas. Natural forests (nature conservation areas, strictly protected by law) cover $5.4 \%$ of the total river basin area. These areas are also included in the Natura 2000-network of the EU. Moreover, the Simojärvi lake and the river itself have been protected. Large conservation areas for peatlands are also included in the national conservation programme. Urban areas cover only $0.06 \%$ and agricultural fields $2.7 \%$ of the catchment area (Perkkiö et al., 1995).

The river Simojoki has two discharge gauging stations; one is located at the river outlet, the other at the Hosionkoski rapids (Fig. 1) (Hyvärinen, 1996). Mean daily flow at the outlet was $37.2 \mathrm{~m}^{3} \mathrm{~s}^{-1}$ during 1965-1990.

The $\mathrm{N}$ concentration data were obtained from the water quality data base operated by the Finnish environment authorities, the Finnish Environment Institute (SYKE) and regional environment centres. Sampling frequency at the outlet of the Simojoki river (Fig. 1) was 9-17 samples $\mathrm{yr}^{-1}$ during 1982-2000. Total $\mathrm{N}$ was analysed as $\mathrm{NO}_{3}-\mathrm{N}$ after oxidation with $\mathrm{K}_{2} \mathrm{~S}_{2} \mathrm{O}_{8}$. $\mathrm{NH}_{4}-\mathrm{N}$ was analysed by a spectrophotometric method with hypochlorite and phenol, and $\mathrm{NO}_{3}-\mathrm{N}$ by the cadmium amalgam method (in fact $\mathrm{NO}_{3}-\mathrm{N}$ was analysed as $\mathrm{NO}_{3}-\mathrm{N}+\mathrm{NO}_{2}-\mathrm{N}$, the $\mathrm{NO}_{2}-\mathrm{N}$ fraction being insignificant). Organic $\mathrm{N}$ was calculated for each sampling occasion as the difference between total and inorganic nitrogen.

\section{INCA MODEL DESCRIPTION}

On the basis of earlier work by Whitehead et al. (1998), a new version of the process-based and semi-distributed INCA model has now been developed (Wade et al., 2002). This model integrates hydrology, catchment and river $\mathrm{N}$ processes, and simulates daily $\mathrm{NO}_{3}-\mathrm{N}$ and $\mathrm{NH}_{4}-\mathrm{N}$ concentrations as time series at key sites, as profiles down the river system or as statistical distributions. Sources of nitrogen include atmospheric deposition, the terrestrial environment, urban areas and direct discharges.

In the INCA model, hydrologically effective rainfall (HER), which is defined as that part of total incident precipitation which reaches stream channels as runoff, is used to drive the water flow and nitrogen fluxes through the catchment system. Hydrology within a catchment is modelled using a simple two-box approach, with key reservoirs of water in the reactive soil zone and deeper groundwater zone. The flow from the zones is calculated by the following equations (Whitehead et al., 1998):

$$
\begin{aligned}
& \text { Soil zone } \quad d x_{1} \quad 1 \\
& \bar{I}=-\left(\text { HER }-x_{1}\right) \\
& \text { dt } T_{1} \\
& \text { Groundwater } d x_{2} \quad 1 \\
& -\overline{-}=-\left(\text { BFI } x_{1}-x_{2}\right) \\
& \text { dt } \quad T_{2}
\end{aligned}
$$

where $x_{1}$ and $x_{2}$ are output flows of the soil zones $\left(\mathrm{m}^{3} \mathrm{~s}^{-1}\right)$. $T_{1}$ and $T_{2}$ are time constants (i.e. residence times in days) associated with the zones, and the base flow index $(B F I)$ is the proportion of water being transferred to the ground water zone.

The river flow model is based on mass balance of flow and uses a multi-reach description of the river system (Whitehead et al., 1998). Flow variation within each reach is determined by a non-linear reservoir model.

$$
\frac{d S(\mathrm{t})}{d t}=I(t)-Q(t)
$$

where $I$ is inflow $\left(\mathrm{m}^{3} \mathrm{~s}^{-1}\right), Q$ is outflow $\left(\mathrm{m}^{3} \mathrm{~s}^{-1}\right), S$ is storage $\left(\mathrm{m}^{3} \mathrm{~s}^{-1}\right)$ and $t$ is time.

$$
S(t)=T(t) * Q(t)
$$

where $T$ is a travel time parameter

$$
T(t)=\frac{L}{v(T)}
$$

where $L$ is the reach length $(\mathrm{m})$ and $v$ is the mean flow velocity in the reach $\left(\mathrm{m} \mathrm{s}^{-1}\right)$. Mean flow velocity is related to discharge, $Q$, through 


$$
v(t)=a Q(t)^{b}
$$

where $a$ and $b$ are constants, which can be estimated from tracer experiments or from theoretical considerations (Whitehead et al., 1998).

\section{WATERSHED FORECASTING AND SIMULATION} SYSTEM (WSFS)

The WSFS has been widely used in Finland since 1990 (Vehviläinen, 1994). It includes model applications for 20 catchments ranging from $600 \mathrm{~km}^{2}$ to $60000 \mathrm{~km}^{2}$ and covers $85 \%$ of Finland. The catchments are divided into small homogeneous sub-basins according to elevation, land use, snow distribution and lakes according to the classification used at SYKE (Ekholm, 1993). Each model consists of 10 100 independent sub-basins $\left(50-500 \mathrm{~km}^{2}\right)$ with simulations of areal precipitation, temperature, water equivalent of snow, soil moisture, changes in subsurface and groundwater storage, and formation of runoff. The basic component of a catchment model is a conceptual hydrological model which simulates runoff using precipitation, potential evaporation and temperature as inputs. The principles of the WSFS are based on the HBV model (Bergström, 1976). The system is commonly used for flood forecasts, water resources management and supervision purposes.

\section{MODEL INPUT DATA}

\section{Land use}

The INCA model application utilises the most recent satellite image-based land use and forest classification data for Finland (Vuorela, 1997), supplemented with satellite imagebased maps of final cuttings in mineral and organic soils, provided by the Finnish Forest Research Institute (FFRI) (Varjo, unpublished). Two Landsat TM 5 satellite images, 191/14A from 20th July 1987 and 191/14 from 8th August 1994, were applied for the detection of final cuttings in the area. Channels $1-5$ and 7 were applied in the analysis because of coarse spatial resolution of channel 6 . The images were registered together and rectified to the Finnish Uniform co-ordinate system applying a first-order polynomial model and the nearest-neighbour resampling method. The pixel size applied was $25 \times 25 \mathrm{~m}$. The identification of land use change was based on differences in segment mean intensities of the two images.

The accuracy in the identification of final cuttings was evaluated by comparing the final cut classification map with the National Forest Inventory field measurements from 1994. In this comparison, the clear-cuts, and partial cuts where seed trees were left for natural regeneration, were considered as final cuttings and other field plots were considered as unchanged. According to this, the overall classification accuracy was $88 \%$, which is a slight overestimate for peat land and a slight underestimate for mineral soil.

Six land-use classes were defined in the nine sub-basins of the river Simojoki; cut areas on mineral and organic soils, 'natural state' mineral and organic soil forests, arable land and open water surface (Table 1). The overall lake percentage $(5.7 \%)$ is low compared to typical Finnish conditions. In fact, the only large lake is lake Simojärvi, located in the uppermost sub-basin.

\section{Hydrological model input}

Hydrologically effective rainfall (HER) was calculated as water balance from the WSFS results:

$$
H E R=(P+M)-E T-\Delta S
$$

where $P$ is liquid precipitation, $M$ is snowmelt, $E T$ is evapotranspiration and $S$ is soil water storage. These are direct output variables from WSFS.

Measured flow during 1994-1996 was used for calibration, because these years correspond to the GIS-based land use classification. The year 1996 corresponded well with the long-term average flow and, in particular, the volume and timing of the spring flood was in good agreement with observations. On average, the years 1994 and 1995 corresponded well with the long term average flow, but both volume and timing of the spring flood were somewhat different from an average year. In 1995 and 1996, the autumn and early winter discharges were higher than in an average year.

\section{Parameterisation}

The base flow index was calculated using the smoothed minima method described by Gustard et al. (1989). The flow velocity parameters, $a$ and $b$, were derived from a onedimensional river flow model. Time constants for the soil reactive zone and the groundwater zone were calibrated against the peaks of the hydrograph. Hydraulic conductivity was assumed to be lower in organic soil than in mineral soil. Time constants were assumed to be lower in forest cut areas than in forested areas giving higher flow peaks in the cut areas. The parameters used are presented in Table 2. 
Table 1. The areal distribution of land use classes in sub-basins

\begin{tabular}{llllllll}
\hline Catchment & Area & $\begin{array}{l}\text { Forest } \\
\text { mineral soil } \\
{[\%]}\end{array}$ & $\begin{array}{l}\text { Forest, cut } \\
\text { mineral soil } \\
{[\%]}\end{array}$ & $\begin{array}{l}\text { Forest } \\
\text { organic soil } \\
{[\%]}\end{array}$ & $\begin{array}{l}\text { Forest, cut } \\
\text { organic soil } \\
{[\%]}\end{array}$ & $\begin{array}{l}\text { Arable } \\
{[\%]}\end{array}$ & $\begin{array}{l}\text { Open } \\
\text { water } \\
{[\%]}\end{array}$ \\
\hline 64.01 & 412 & 37 & 4 & 52 & 1 & 4 & 2 \\
64.02 & 375 & 29 & 3 & 63 & 1 & 2 & 2 \\
64.03 & 557 & 37 & 4 & 52 & 0 & 3 & 4 \\
64.04 & 446 & 32 & 3 & 59 & 0 & 1 & 5 \\
64.05 & 630 & 43 & 3 & 35 & 0 & 1 & 18 \\
64.06 & 147 & 28 & 2 & 67 & 1 & 0 & 2 \\
64.07 & 245 & 26 & 4 & 68 & 1 & 0 & 1 \\
64.08 & 201 & 40 & 6 & 52 & 0 & 1 & 1 \\
64.09 & 147 & 41 & 3 & 47 & 0 & 1 & 8 \\
\hline
\end{tabular}

Table 2. Parameter values used to calibrate the hydrological component of the INCA model

\begin{tabular}{lcc}
\hline Parameter & Unit & Value \\
\hline Initial values & & \\
Surface flow & $\mathrm{m}^{3} \mathrm{~s}^{-1}$ & 0.005 \\
Sub-surface flow & $\mathrm{m}^{3} \mathrm{~s}^{-1}$ & 0.005 \\
Controls & & \\
Sustainable surface flow & $\mathrm{m}^{3} \mathrm{~s}^{-1}$ & 0.001 \\
Sustainable sub-surface flow & $\mathrm{m}^{3} \mathrm{~s}^{-1}$ & 0.001
\end{tabular}

Parameters

Time constants

Groundwater zone

$\begin{array}{lll}\text { forest, mineral and organic soil } & \text { d } & 8 \\ \text { forest, mineral and organic soil, cut } & \text { d } & 7 \\ \text { arable } & \text { d } & 8\end{array}$

Soil reactive zone

$$
\begin{aligned}
& \text { forest, mineral soil } \\
& \text { forest, mineral soil, cut } \\
& \text { forest, organic soil } \\
& \text { forest, organic soil, cut } \\
& \text { arable }
\end{aligned}
$$

Open water surface

Flow a

Flow b

Base flow index

Sub-basins 64.01, 64.02, 64.06, 64.07

Sub-basins 64.03, 64.04, 64.05, 64.08, 64.09

$\begin{array}{ll}\mathrm{d} & 3 \\ \mathrm{~d} & 1 \\ \mathrm{~d} & 5 \\ \mathrm{~d} & 2 \\ \mathrm{~d} & 4 \\ \mathrm{~d} & 5 \\ - & 0.26 \\ - & 0.32 \\ & \\ - & 0.63 \\ - & 0.62\end{array}$




\section{Calibration of the hydrological component of the INCA model}

\section{LUMPED AND SEMI-DISTRIBUTED \\ CALIBRATION}

The simulated $\mathrm{N}$ concentrations in both the terrestrial and in-stream components of the model depend on water volumes. Hence, the hydrological component of the INCA model should be calibrated first before moving on to the catchment $\mathrm{N}$ process model work.

Lumped input data were calculated for the whole catchment (Fig. 2) and semi-distributed input data for each of the nine sub-basins (Table 3). The discharge of the river Simojoki was simulated using both input data sets and compared with the observed discharge at two locations along
Table 3. Three-year averages (1994-1996) of hydrologically effective rainfall (HER), air temperature and precipitation (P) in sub-basins of the River Simojoki.

\begin{tabular}{llll}
\hline Sub-basin & $\begin{array}{l}\text { HER } \\
\left(m m y r^{-1}\right)\end{array}$ & $\begin{array}{l}T \\
\left({ }^{\circ} \mathrm{C}\right)\end{array}$ & $\begin{array}{l}P \\
\left(m m y r^{-1}\right)\end{array}$ \\
\hline 64.01 & 309 & 0.9 & 500 \\
64.02 & 308 & 1.4 & 518 \\
64.03 & 347 & 1.4 & 503 \\
64.04 & 349 & 1.4 & 517 \\
64.05 & 287 & 1.6 & 486 \\
64.06 & 375 & 1.2 & 552 \\
64.07 & 402 & 1.5 & 546 \\
64.08 & 399 & 1.4 & 527 \\
64.09 & 300 & 1.4 & 537 \\
\hline
\end{tabular}
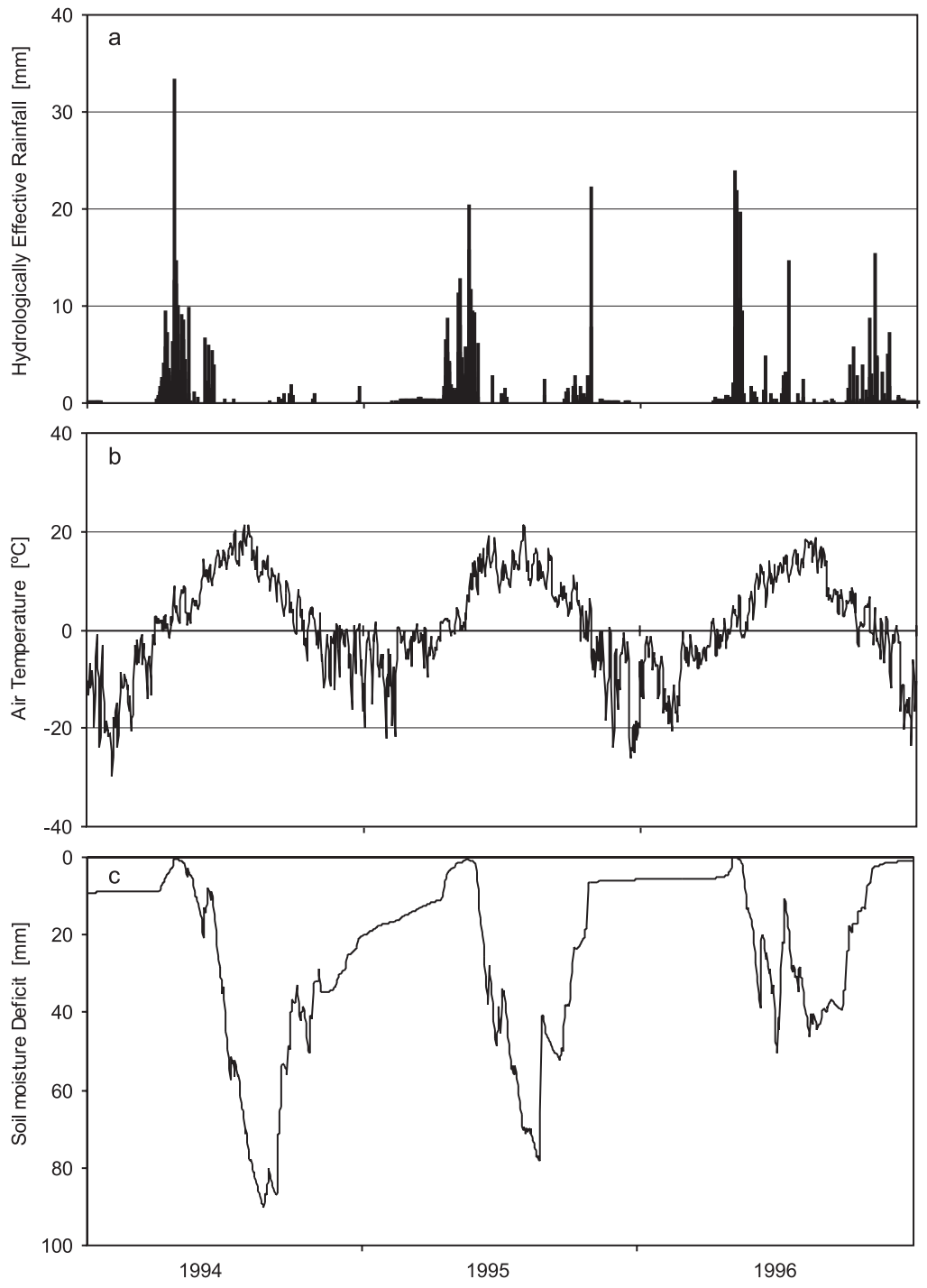

Fig. 2. Lumped hydrometeorological input data for the three years 1994-1996 


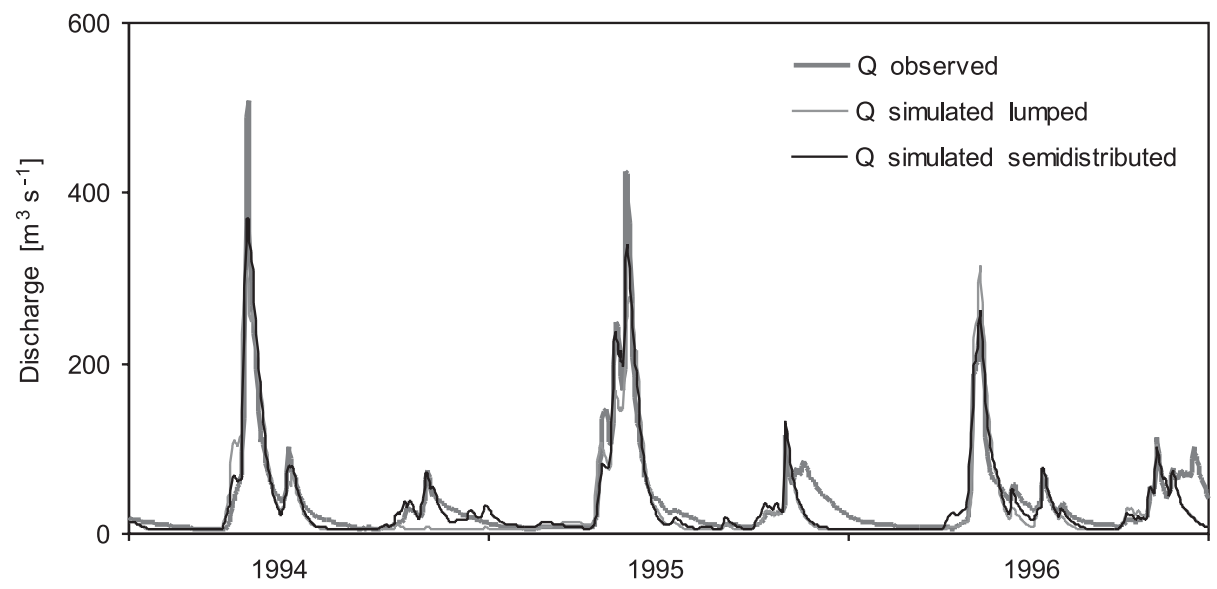

Fig. 3. Observed discharge in the river Simojoki outlet in 1994-1996 compared with simulated discharge using lumped and semi-distributed input data

the river, at the river outlet (Fig. 3) and at the Hosionkoski rapids. The simulated discharges based on semi-distributed input data fitted the observed values better than those based on lumped input data. The Nash and Sutcliffe (1970) efficiency $\mathrm{R}^{2}$ was 0.78 v. 0.70 at Hosionkoski and $0.88 v$. 0.78 at the river outlet. Refsgaard and Knudsen (1996) compared three hydrological models with different spatial resolutions and they concluded that all models performed equally well when data from at least one year were available for calibration. However, the distributed models performed marginally better in cases where no calibration was allowed. Krysanova et al. (1999) compared lumped and distributed versions of the HBV model and found that the estimated flow was improved when applying the distributed $v$. the lumped model. They concluded that the more pronounced the representation of catchment heterogeneity, the better was the performance of the distributed model version.

The timing of flow peaks was simulated rather well with both approaches, although the semi-distributed input data gave a more realistic simulation of low flow periods and the magnitude of spring flow peaks (Fig. 3). Discharges in autumn1994 were simulated well using semi-distributed input data, but both approaches failed to simulate the autumn discharges in 1995 and 1996. However, the discharge observations during late autumn/early winter may be uncertain due to ice formation in the river (Hyvärinen, 1986). Ice damming, measured as increase in water level, is maximal when discharge is high at the beginning of winter and decreases towards the end of the winter. In most rivers damming is a largely random process which varies during the winter and between years. Although the observations are corrected manually on the basis of information from the local observer, a periodical overestimation of river discharge cannot be excluded. It seems that the observed autumn discharge was overestimated in 1995 and 1996, when the air temperature was below $0^{\circ} \mathrm{C}$ for long periods but discharge increased (Fig. 4). In the warmer autumn of 1994, observed and simulated discharge were close to each other (Fig. 4). In WSFS simulations, precipitation is assumed to change from liquid to snow when the air temperature drops near $0^{\circ} \mathrm{C}$ with consequent decrease in surface runoff to the river.

The annual water balances over the three-year period improved when semi-distributed data were used (Table 4). Seasonal water balances were adequate during the spring months April-June in each calibration year. During summer low flow in July-September, semi-distributed input data clearly improved the water balance from $47 \%-68 \%$ to $72 \%-$ $80 \%$ of observed. In late autumn and winter, water balances were affected by the ice formation phenomena described above. During winter low flow in January-March, water volumes were rather low.

The timing and magnitude of high flow peaks is very important when simulating $\mathrm{N}$ fluxes, because under present climatic conditions most of the $\mathrm{N}$ export occurs during periods with high flow. Particularly, the early phase of the spring flood is a critical period due to 'flushing' of inorganic $\mathrm{N}$ from catchment soils and from melting snow, followed by dilution processes (Arheimer et al., 1996). Thus, a successful model calibration for these high flow periods is extremely important for estimating the total load of $\mathrm{N}$ to the rivers and coastal waters. However, if impacts of possible climate changes are to be studied, the low flow periods are also important. Vehviläinen and Huttunen (1996) considered that the assumed climate change (increase in temperature and precipitation) will change the annual distribution of runoff significantly. Their model estimates a strong increase in winter runoff due to an increase of snowmelt during winter. During summer, the increased soil and lake 

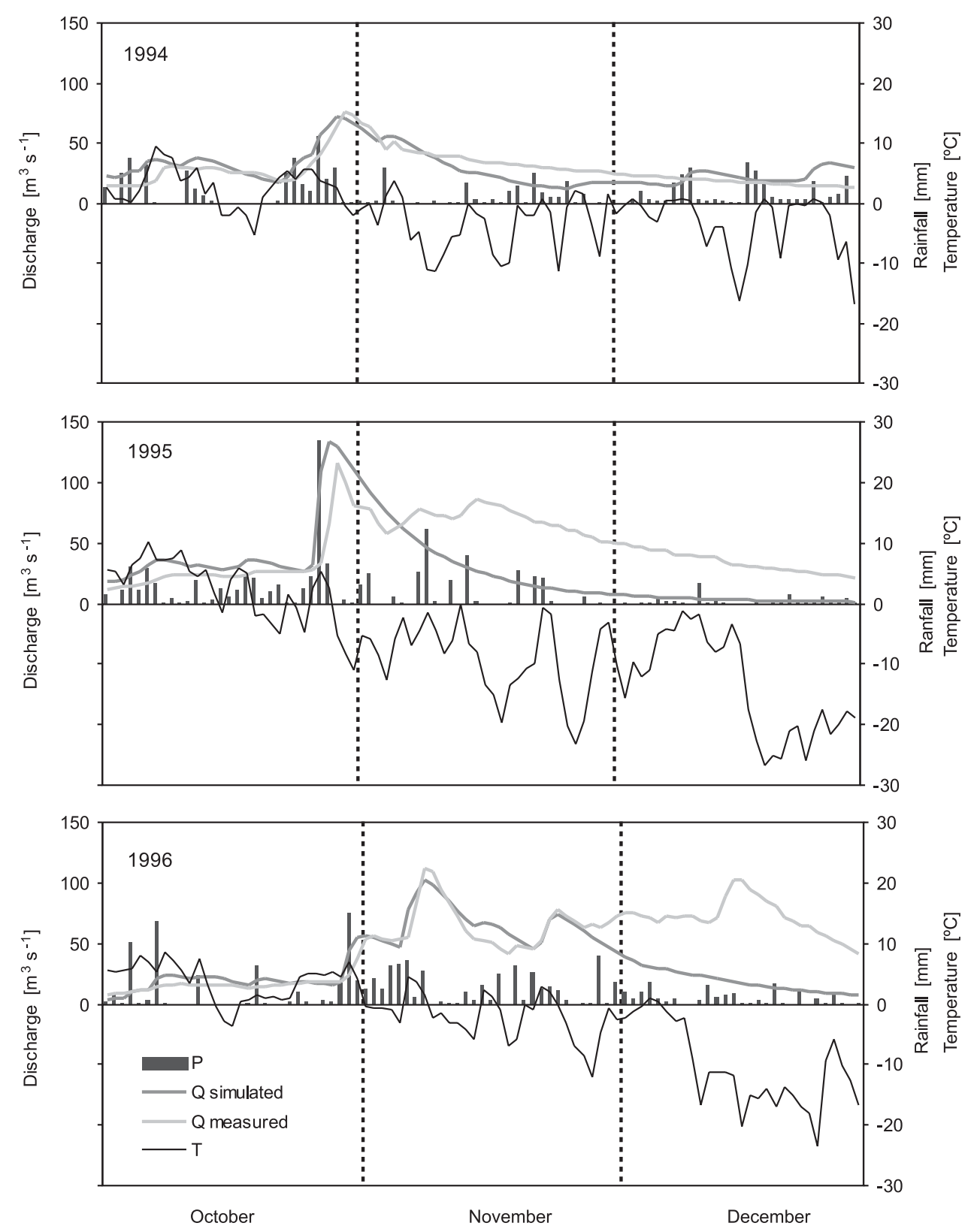

Fig. 4. Air temperature and precipitation for the Simojoki catchment, and observed and simulated (semidistributed input data) discharge in the river Simojoki outlet in October-December in 1994-1996

evaporation lead to a decrease in the summer minimum discharge.

\section{HYDROLOGY AND FORESTRY}

Both WSFS and INCA are semi-distributed models. WSFS simulates hydrology at a sub-basin scale, but does not take into account the land-use classes within the sub-basins. Input data to the hydrological component of the INCA model may relate to the whole river basin or to the individual sub-basins. The velocity of the water passing through the soil layers can be adjusted by residence times and the amount of water present in the soil reactive zone against the groundwater zone is adjusted by the base flow index. These parameters, however, do not influence the actual amount of water discharging from a certain land-use class. Because the hydrological inputs relate to the whole river basin or the sub-basins rather than to the land-use classes, care should 
Table 4. Observed and simulated annual and seasonal runoff in 1994-1996 at the outlet of the river Simojoki

\begin{tabular}{|c|c|c|c|c|c|c|}
\hline \multirow[t]{2}{*}{ Year } & \multirow[t]{2}{*}{ Period } & \multirow{2}{*}{$\begin{array}{l}\text { Observed runoff } \\
\text { (mm) }\end{array}$} & \multicolumn{2}{|c|}{ Simulated runoff } & \multicolumn{2}{|c|}{ Proportion of observed } \\
\hline & & & $\begin{array}{l}\text { lumped } \\
(\mathrm{mm})\end{array}$ & $\begin{array}{l}\text { semi-distributed } \\
(\mathrm{mm})\end{array}$ & $\begin{array}{l}\text { lumped } \\
(\%)\end{array}$ & $\begin{array}{l}\text { semi-distributed } \\
(\%)\end{array}$ \\
\hline 1994 & & 354 & 288 & 353 & 81 & 100 \\
\hline & Jan-Mar & 25 & 14 & 15 & 56 & 60 \\
\hline & Apr-Jun & 230 & 247 & 246 & 107 & 107 \\
\hline & Jul-Sep & 29 & 14 & 21 & 48 & 72 \\
\hline & Oct-Dec & 70 & 12 & 72 & 17 & 103 \\
\hline 1995 & & 435 & 335 & 371 & 77 & 85 \\
\hline & Jan-Mar & 20 & 21 & 26 & 105 & 130 \\
\hline & Apr-Jun & 265 & 239 & 248 & 90 & 94 \\
\hline & Jul-Sep & 36 & 17 & 27 & 47 & 75 \\
\hline & Oct-Dec & 113 & 58 & 70 & 51 & 62 \\
\hline 1996 & & 367 & 308 & 322 & 84 & 88 \\
\hline & Jan-Mar & 28 & 13 & 15 & 46 & 54 \\
\hline & Apr-Jun & 156 & 164 & 173 & 105 & 111 \\
\hline & Jul-Sep & 60 & 41 & 48 & 68 & 80 \\
\hline & Oct-Dec & 124 & 90 & 86 & 73 & 69 \\
\hline
\end{tabular}

be taken in using the INCA model in studies of changing land use, especially if the change in land use is expected to have a major effect on hydrology.

In the river Simojoki basin, the main human impact is forestry. According to Seuna (1988), forest cutting increased runoff by $20 \%$ from organic soils and by $15 \%$ from mineral soils during the subsequent three years. According to Alatalo (2000), forest cutting increased runoff by $40 \%$ in a mineral soil-dominated catchment, and forest cutting and ditching increased runoff by $21 \%$ in an organic soil catchment. However, these studies have been conducted in very small catchments (only a few hectares), and the combined impact of the mosaic of small forest treatment areas in large river basins is unclear (e.g. Buttle and Metcalfe, 2000). Hyvärinen and Vehviläinen (1981) found a slight $(\sim 5 \%)$ increase in spring high flow in some lake basins $\left(200-3500 \mathrm{~km}^{2}\right)$ in central and northern Finland due to forest drainage.

\section{$\mathbf{N}$ flux and $\mathbf{N}$ dynamics in the river}

\section{RIVERINE N FLUXES}

The river Simojoki is close to its natural state. The river basin has a relatively closed $\mathrm{N}$ cycle with low input and output fluxes of inorganic N. During 1982-2000, the average total $\mathrm{N}$ flux to the sea was 715 tonnes $\mathrm{yr}^{-1}$. This corresponds to $230 \mathrm{~kg} \mathrm{~km}^{-2} \mathrm{yr}^{-1}$, i.e. $20-30 \%$ of the level detected in agriculture-dominated river basins in southern Finland (Vuorenmaa et al., 2002).

Of the total $\mathrm{N}$ flux, $6 \%$ was $\mathrm{NH}_{4}-\mathrm{N}, 14 \% \mathrm{NO}_{3}-\mathrm{N}$, and $80 \%$ organic $\mathrm{N}$. Considerable amounts of organic matter and organic $\mathrm{N}$ - are being leached from these northern boreal forests and forest wetlands, whereas inorganic $\mathrm{N}$ leaching is low. Retention of $\mathrm{N}$ was estimated to be negligible in the river Simojoki itself (Lepistö et al., 2001), due to the low lake percentage and to the northern boreal environment, where denitrification plays only a minor role.

\section{SEASONAL VARIATION OF N FRACTIONS IN THE RIVER}

$\mathrm{N}$ uptake by vegetation, immobilisation and mineralisation in catchment soils, accumulation in the seasonal snowpack, and flow dynamics are the most important factors affecting seasonal variation of $\mathrm{NO}_{3}-\mathrm{N}$ in surface waters. In northern boreal mineral and organic soil forests, inorganic $\mathrm{N}$ is usually retained effectively during the growing season, such that streamwater concentrations often are negligible (Fig. 5).

$\mathrm{NO}_{3}-\mathrm{N}$

The seasonal variation of $\mathrm{NO}_{3}-\mathrm{N}$ in the river Simojoki river during 1982-2000 followed the 'normal', seasonal pattern 

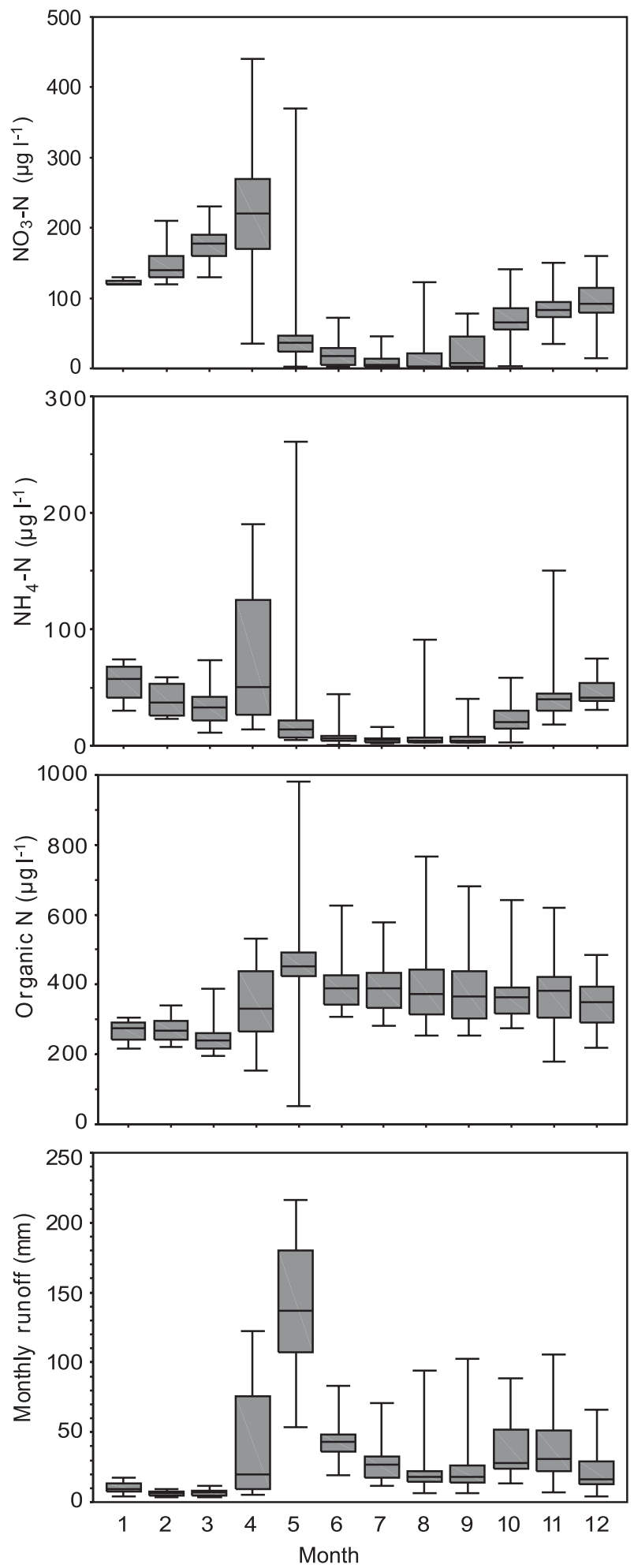

Fig. 5. Monthly Box-Whisker plots showing annual dynamics of different $N$ fractions and runoff in 1982-2000 at the outlet of the river Simojoki

of a non-polluted and undisturbed northern river, with low or undetectable concentrations during summer and appreciably higher concentrations during the dormant season. Both the median concentration $\left(220 \mu \mathrm{g} \mathrm{l}^{-1}\right)$ and the inter-annual variation were highest in April. The clear increase in nitrate concentrations at the onset of the snowmelt period in April, and a clearly higher concentration level during spring compared with autumn indicates the importance of the release of $\mathrm{N}$ from the snowpack and/or soil (e.g. Arheimer et al., 1996; Williams et al., 2001). After the spring flood, N limitation sets in with extensive plant uptake and near-zero $\mathrm{NO}_{3}-\mathrm{N}$ concentrations, and a second increase occurs due to leaching during autumn rains.

$\mathrm{NH}_{4}-\mathrm{N}$

A seasonal pattern of $\mathrm{NH}_{4}-\mathrm{N}$ is observed which is similar to that of $\mathrm{NO}_{3}-\mathrm{N}$, except that the concentration levels are less than half of those recorded for $\mathrm{NO}_{3}-\mathrm{N}$. The $\mathrm{NH}_{4}-\mathrm{N}$ concentrations observed during the growing season were even lower than those of $\mathrm{NO}_{3}-\mathrm{N}$, most probably due to preferential biological uptake of $\mathrm{NH}_{4}-\mathrm{N}$. Furthermore, two-thirds of the catchments studied by Arheimer et al. (1996) also had significantly lower concentrations during the growing season compared with the dormant season. The most significant differences between $\mathrm{NH}_{4}-\mathrm{N}$ and $\mathrm{NO}_{3}-\mathrm{N}$ concentrations were observed during the winter months January-March, when runoff is low, soil is deeply frozen, and the river has a thick ice cover. At this time, $\mathrm{NH}_{4}-\mathrm{N}$ concentrations decreased while $\mathrm{NO}_{3}-\mathrm{N}$ concentrations increased, indicating nitrification during winter, either in groundwater discharging to the river system or in the river itself. The responsiveness of microbial processes of nitrogen cycling at low temperature is critical to assessing the nitrogen-supplying power of soils in cold regions (Marion, 1995).

\section{ORGANIC N}

There was less variability in the seasonal pattern of organic than of inorganic N. Concentrations did increase significantly during the spring flood, particularly in May, due to erosioninduced leaching processes. Arheimer et al. (1996) found significant positive correlations between flow and organic $\mathrm{N}$ concentrations in $70 \%$ of the 20 forested catchments studied in Sweden and Finland. Enhanced concentrations of organic$\mathrm{N}$ during periods of high flow may be an integrated effect of erosion losses in peat areas and eluviation of soluble fulvic acids (Roberts et al., 1984). Concentrations during summer, from June to August, tend to be relatively high due to biological activity within the aquatic ecosystem. The sources of organic $\mathrm{N}$ may change with time. The results from a highelevation catchment in the Rocky Mountains, USA, suggest that sources of organic matter changed from humidified and condensed terrestrial sources at the initiation of snowmelt runoff to aquatic sources during the late summer and autumn months (Williams et al., 2001). 


\section{Concluding remarks}

The simulated nitrogen concentrations in both the terrestrial and in-stream components of the model depend on water volumes. Hence, the hydrological component of the INCA model should be calibrated first before moving on to the catchment $\mathrm{N}$ process model work. The study showed that the hydrological part of the INCA model could be calibrated successfully in the river Simojoki catchment. The best results were achieved using a semi-distributed input to the hydrological component of the INCA model. The timing of flow peaks was simulated rather well with both approaches, although the semi-distributed input data gave a more realistic simulation of low flow periods and the magnitude of spring flow peaks. The water balance over the three-year period clearly improved when using semi-distributed data. Uncertainties in the hydrograph may occur during late autumn due to ice formation in the river.

In cases where input data are given for the whole catchment or for the individual sub-basins instead of landuse class, care should be taken in using the INCA model in studies of changing land use, especially if the change in land use is expected to have a major effect on the hydrology. Although the overall effect of changing land use on river discharge may be minor, the subsurface runoff should be correct in order to be able to estimate the total $\mathrm{N}$ load from a certain land-use class. The river Simojoki basin has a relatively closed $\mathrm{N}$ cycle with minor inorganic $\mathrm{N}$ input and output fluxes. A crucial question is whether a possible climate change will enhance mineralisation and subsequent leaching of $\mathrm{N}$ to the river and coastal waters.

\section{Acknowledgements}

This study was supported by the Comission of the European Union, the INCA project (EVK1-CT-1999-00011). The authors thank Dr. Bertel Vehviläinen, SYKE, for providing WSFS model simulations, and Dr. Jari Varjo, Finnish Forest Research Institute FFRI, for providing satellite image-based maps of final cuttings.

\section{References}

Abbott, M.B., Bathurst, J.C., Cunge, J.A., O'Connell, P.E. and Rasmussen, J., 1986. An introduction to the European Hydrological System-Système Hydrologique Européen, SHE. Parts 1 \& 2. J. Hydrol., 87, 45-77.

Alatalo, M., 2000. The effects of forest management on the loading of nutrient and suspended solids. Metsätaloustoimenpiteistä aiheutunut ravinne- ja kiintoainekuormitus [in Finnish]. The Finnish Environment 381. Helsinki. 64 pp.
Arheimer, B., Andersson, L. and Lepistö, A., 1996. Variation of nitrogen concentration in forest streams - influences of flow, seasonality and catchment characteristics. J. Hydrol., 179, 281304.

Arnold, J.G., Srinivasin, R., Muttiah, R.S. and Williams, J.R., 1998. Large Area Hydrologic Modeling and Assessment: Part I. Model Development. JAWRA 34, 73-89.

Bergström, S., 1976. Development and application of a conceptual runoff model for Scandinavian catchments. SMHI 117. Swedish Meteorological and Hydrological Institute. Norrköping, Sweden.

Bosch, J.M. and Hewlett, J.D., 1982. A review of catchment experiments to determine the effect of vegetation changes on water yield and evaporation. J. Hydrol, . 55, 3-23.

Buttle, J.M. and Metcalfe, R.A., 2000. Boreal forest disturbance and streamflow response, northeastern Ontario. Can. J. Fish. Aquat. Sci. 57, 5-18.

Cheng, J.D., 1989. Streamflow changes after clear-cut logging of a pine beetle infested watershed in southern British Columbia, Canada. Water Resour. Res. 25, 449-456.

Gundersen, P., 1992. Mass balance approaches for establishing critical loads for nitrogen in terrestrial ecosystems. In: Critical load for nitrogen - a workshop report, P. Grennfelt and E. Thörnelöf (Eds.), Lökeberg, Sweden, 6-10 April 1992. Nordic Council of Ministers, Copenhagen. Nord 41, 55-109.

Gustard, A., Roald, L.A., Demuth, S., Lumadjeng, H.S. and Gross, R., 1989. Flow Regimes from Experimental and Network Data. Volume I Hydrological Studies. Institute of Hydrology, UK.

Ekholm, M., 1993. Drainage basins in Finland. Suomen vesistöalueet. [in Finnish] Publ. Water Environ.t Admin. - series A $126.166 \mathrm{pp}$.

Hyvärinen, V., 1986. Some practical aspects of graphical ice reduction. In: Field Measurements Under Winter Conditions, H.S. Santeford (Ed.). Proc. Sixth Inter. Northern Research Basins Symposium/Workshop. Michigan Technological University, Houghton, Michigan, 26-30 April 1986. 25-29.

Hyvärinen, V., 1996. Hydrological yearbook 1993. Hydrologinen vuosikirja 1993 [in Finnish] The Finnish Environment 69.

Hyvärinen, V. and Vehviläinen, B., 1981. The effects of climatic fluctuations and man on discharge in Finnish river basins. Publ. of the Water Research Institute 43,15-23.

Kahru, M., Horstman, U. and Rud, O., 1994. Satellite detection of increased Cyanobacteria blooms in the Baltic Sea: natural fluctuation or ecosystem change? Ambio 23: 469-472.

Krysanova, V., Bronstert A. and Müller-Wohlfeil, D.-I., 1999. Modelling river discharge for large drainage basins: from lumped to distributed approach. Hydrolog. Sci. 44, 313-331.

Kuparinen, J. and Tuominen, L., 2001. Eutrophication and selfpurification: Counteractions forced by large-scale cycles and hydrodynamic processes. Ambio 30: 190-194.

Lepistö, A., Kenttämies, K. and Rekolainen, S., 2001. Modeling combined effects of forestry, agriculture and deposition on nitrogen export in a northern river basin in Finland. Ambio 30, 338-348.

Lindström, G., Johansson, B., Persson, M., Gardelin, M. and Bergström, S., 1997. Development and test of the distributed HBV-96 hydrological model. J. Hydrol., 201, 272-288.

Marion, G.M., 1995. Freeze-thaw processes and soil chemistry. US Army Corps of Engineers. Cold Regions Research \& Engineering Laboratory. Special Report 95-12. 28 pp.

Nash, J.E. and Sutcliffe J.V., 1970. River flow forecasting through conceptional models. 1. A discussion of principles. J. Hydrol., 10, 282-290.

Perkkiö, S., Huttula, E. and Nenonen, M., 1995. Water protection plan for the Simojoki river basin. Simojoen vesistön vesiensuojelusuunnitelma [in Finnish]. Publ. Water Environ. Admin. - series A 200. 102 pp. 
Refsgaard, J.C. and Knudsen, J., 1996. Operational validation and intercomparison of different types of hydrological models. Water Resour. Res. 32, 2189-2202.

Roberts, G., Hudson, J.A. and Blackie, J.R., 1984. Nutrient inputs and outputs in a forested and grassland catchment at Plynlimon, Mid Wales. Agr. Water Manage. 9, 177-191.

Sachs, D.L., Sollins, P. and Cohen, W.B., 1998. Detecting landscape changes in the interior of British Columbia from 1975 to 1992 using satellite imagery. Can. J. Fish. Aquat. Sci. 28, 23-36.

Seuna, P., 1988. Effects of clear-cutting and forestry drainage on runoff in Nurmes-study. Proceedings of the international symposium on the hydrology of wetlands in temperate and cold regions. Joensuu, Finland 6-8 June 1988. Publications of the Academy of Finland 1, 122-134.

Vehviläinen, B., 1994. The watershed simulation and forecasting system in the National Board of Water and the Environment. Publ. of the Water and Environment Research Institute No 17, 3-16.

Vehviläinen, B. and Huttunen, M., 1996. Climate change and water resources in Finland. The Finnish Research Programme on Climate Change. Second Final Report. SILMU. Publications of the Academy of Finland 4, 24-130.

Vuorela, A. 1997. Satellite image based land cover and forest classification of Finland. In: Proc. Finnish-Russian Seminar on Remote Sensing, R. Kuittinen (Ed.), Helsinki, 29 August-1 September, 1994. Reports of the Finnish Geodetic Institute 97 2, 42-52.
Vuorenmaa, J., Rekolainen, S., Lepistö, A., Kenttämies, K. and Kauppila, P., 2002. Losses of nitrogen and phosphorus from agricultural and forest areas in Finland during the 1980s and 1990s. Environ. Monit. Assess., 76, 213-248.

Wade, A.J., Durand, P., Beaujouan, V., Wessels, W., Raat, K., Whitehead, P.G., Butterfield, D., Rankinen, K. and Lepistö, A., 2002. A nitrogen model for European catchments: New model structure and equations. Hydrol. Earth System Sci., 6, 559-582.

Whitehead, P.G., Wilson, E.J. and Butterfield, D., 1998. A semidistributed Integrated Nitrogen model for multiple source assessment in Catchments (INCA): Part I-model structure and process equations. Sci. Total Environ., 210/211, 547-558.

Williams, J.R., Renard, K.G. and Dyke, P.T., 1984. EPIC - a new model for assessing erosion's effect on soil productivity. J. Soil Wat. Conserv. 38, 381-383.

Williams, M.W., Hood, E. and Caine, N., 2001. Role of organic nitrogen in the nitrogen cycle of a high-elevation catchment, Colorado Front Range. Water Resour. Res., 37: 2569-2581.

Wiklander, G., Nordlander, G. and Andersson, R. 1991. Leaching of nitrogen from a forest catchment at Söderåsen in Southern Sweden. Water Air Soil Pollut. 55, 263-282.

Wulff, F. and Rahm, L., 1988. Longterm, seasonal and spatial variations of nitrogen, phosphorus and silicate in the Baltic: an overview. Mar. Environ. Res., 26, 19-37. 